\title{
鉄筋の腐食に起因するひび割れ性状とコンクリートの剥落危険性の評価 CRACKING BEHAVIORS CAUSED BY CORRODING BARS AND RISK ASSESSMENT OF CONCRETE PEELING-OFF
}

\author{
篠原保二*, 丸山裕生**, 山下海斗***, 南 正 樹**** \\ Yasuji SHINOHARA, Hiroki MARUYAMA, Kaito YAMASHITA \\ and Jeongsoo NAM
}

\begin{abstract}
Accelerated corrosion tests were conducted on concrete cylinders installing one reinforcement right in the center to estimate the splitting tensile strength before and after corrosion cracking and to assess the risk of concrete peeling-off. Test results indicated that the splitting tensile strength before cracking nearly didn't deteriorate due to an occasional stain of corrosion product, however, it gradually reduced after outflowing of corrosion product from a connected crack. A simple model was proposed to assess a retention factor of splitting tensile strength with increasing corrosion. Furthermore, a fracture energy of a cracked surface by corrosion was investigated through FE analysis.
\end{abstract}

\section{Keywords Corroded sted bar, Corrosion crack propagation, Splitting tensilestrength, Concrete peding-off, Fracture energy} 腐食鉄筋, 腐食ひび割れ進展, 割裂引張強度, コンクリートの剥落, 破壊エネルギー

\section{1. はじめに}

近年, かぶりコンクリートの剥落など鉄筋コンクリート（以下 RC と略す）造建物の経年劣化に関する問題が顕在化している。特にコ ンクリート片の剥落は, 周囲の人に危害を及ぼす可能性があり, 緊 急性を要する課題である。 RC 造建物の構造性能に最も影響を及ぼ 寸劣化要因は鉄筋腐食であるが, 鉄筋腐食膨張によるひび割れ進展 挙動は, かぶりコンクリートの剥落に対しても甚大な影響を及ぼす と考えられる。筆者ら ${ }^{1)}$ は実物規模の断面 $600 \times 600 \mathrm{~mm}$ に主筋, 横 補強筋を配した RC 柱を対象とし, 高さ $300 \mathrm{~mm}$ でカットオフした 柱要素試験体を用いて, ひび割れ進展挙動を検討するために促進腐 食実験を行った。促進腐食実験終了後, 腐食量の実測のために腐食 鉄筋を取り出寸際, 腐食生成物は主筋間及び横補強筋間に大量に残 留しており, かぶりコンクリートはコア部から容易に剥離した。実 際の RC 造建物の柱・梁部材においても, 内部鉄筋の腐食は, 腐食 膨張によるリングテンションよってひび割れを誘発し,さらに主筋, 横補強筋に沿ったひび割れが連結することにより，かぶりコンクリ 一トの一体性が損なわれ, 剥落の危険性が高まると思われる。しか しながら, 既往の鉄筋腐食に関する研究では, 表面ひび割れ発生時 の限界腐食量を評価する研究が大多数 2),37であり, カバーコンクリー
トの剥落の危険性について検討した研究例は少ない。 本研究では, 知見が不足している表面ひび割れ発生前後の腐食量 と腐食ひび割れ挙動の関係を検証するため, ひび割れ発生前後に設 定した目標積算電流密度に対して, 腐食量の実測を行うとともに, 腐食鉄筋を取り出す際，所定の割裂引張試験を行い，腐食ひび割れ 発生前後のひび割れ面に対する割裂引張強度の低下傾向を定量的に 把握する。さらに, 腐食ひび割れに起因するかぶりコンクリート(コ ンクリート片）の剥落の危険性を評価する尺度として, 鉄筋の腐食 量の増大に伴うコンクリートの割裂引張強度低下率を推定する式を 提案する。前報 ${ }^{4}$ のコンクリート表面の腐食ひび割れ幅から内部鉄 筋の腐食量を推定する式と併せて, 計測が容易なコンクリート表面 の腐食ひび割れ幅から, 内部鉄筋の腐食量, ひび割れ進展挙動およ び割裂引張強度低下率の推定が可能となり, 高経年化 RC 造建物の 継続使用に対する安全性評価に資することができる。

\section{2. 促進腐食実験}

\section{1 割裂引張試験体諸元}

Table 1 に割裂引張試験体の諸元を示す。本研究の目的を達成する ために，実験結果のばらつきを考慮し，設定した目標腐食レベル毎

\footnotetext{
* 東京工業大学未来産業技術研究所 准教授 · 博士 (工学)

** 清水建設 修士(工学)

*** 東京工業大学環境理工学創造専攻 大学院生

**** 東京工業大学フロンティア材料研究所 研究員・博士 (工学)
}

Assoc. Prof., Laboratory for FIRST, Tokyo Institute of Technology, Dr.Eng. Shimizu Corporation, Master of Engineering

Grad. Stud., Dept. of Environmental Sci. and Tech., Tokyo Institute of Technology Researcher, Laboratory for Materials and Structures, Tokyo Institute of Technology, Dr.Eng. 
に繰返し数を 3 体とする促進腐食試験および割裂引張試験を行った。

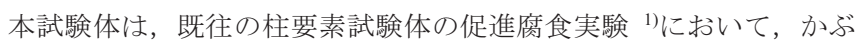
りコンクリートの剥落の要因となった横補強筋間の腐食ひび割れの 一部を, Fig.1 に示すように模擬したものである。試験体寸法 (直径 $150 \mathrm{~mm}$, 長さ $300 \mathrm{~mm}$ ), 腐食対象の鉄筋 D16 およびコンクリート 調合強度 Fc30 は共通であり, 目標腐食レベルのみ変動要因である。 柱要素試験体の促進腐食実験 ${ }^{1)}$ における横補強筋間の腐食ひび割れ を再現するため, 鉄筋 D16 をシリンダーの中心軸に設置し, 腐食ひ び割れを誘導する軸心を対称に相対する $50 \mathrm{~mm}$ 幅以外は, エポキシ コーティングによって防水処置を施した。ただし, エポキシコーテ イングが割裂強度に及ぼす影響を回避するために, 試験体両端の割 裂方向に幅 $50 \mathrm{~mm}$ のテーピングをした後, エポキシコーティングを 施し, 割裂試験前にテーピングと共にエポキシを除去した。

変動要因である促進試験を終了寸る目標積算電流密度については, 既往の実験結果 1 )を参考に腐食生成物が表面に現れる積算電流密度 を, $100 \mathrm{~mA} \cdot \mathrm{h} / \mathrm{cm}^{2}$ とし, その前後で 2 段階の目標值を設定した。試 験体名の最初の C はシリンダー (cylinder) 試験体, 次の数字はかぶり 厚さ $66 \mathrm{~mm}$ (D16 の最大径 $18 \mathrm{~mm})$, 最後の数字が目標積算電流密度

Table 1 List of test specimens

\begin{tabular}{c|c|c|c}
\hline Designation & $\begin{array}{c}\text { Accumulated } \\
\text { current density } \\
\left(\mathrm{mA} \cdot \mathrm{h} / \mathrm{cm}^{2}\right)\end{array}$ & $\begin{array}{c}\text { Number of } \\
\text { specimen }\end{array}$ & Remarks \\
\hline C66-0 & 0 & 3 & Not corroded bar \\
\hline C66-30 & 30 & 3 & Slightly corroded bar \\
\hline C66-100 & $\mathbf{1 0 0}$ & 3 & Corrosion cracking \\
\hline C66-200 & 200 & 3 & Appreciably corroded bar \\
\hline C66-400 & 400 & 3 & Seriously corroded bar \\
\hline
\end{tabular}

Specimens in bold letter are expected to crack in the surface.
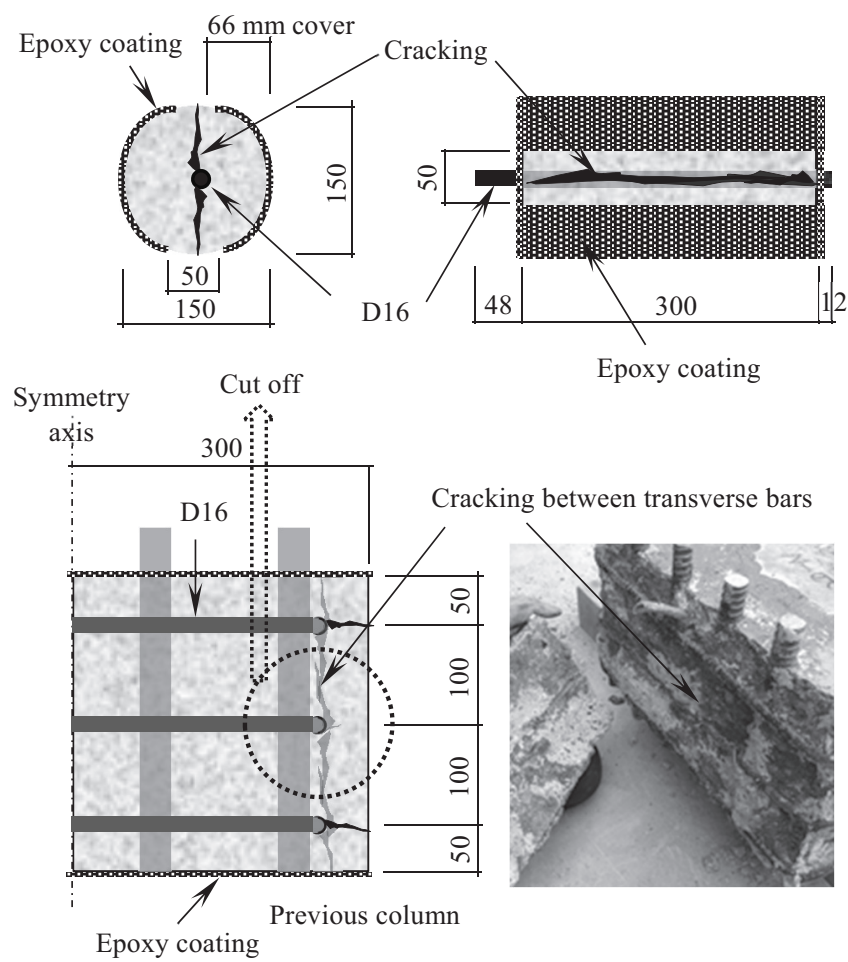

Fig.1 Simplified specimens cut off from previous column specimens
を示している。試験体に用いたコンクリートの調合を Table 2 に, フ レッシュコンクリートおよび打設後 28 日の力学特性を Table 3 に示 す。コンクリートはすべて縦打ちとした。

Table 2 Mix proportions

\begin{tabular}{ccccccc}
\hline $\begin{array}{c}\text { Design } \\
\text { strength }\end{array}$ & $\begin{array}{c}\text { W/C } \\
(\%)\end{array}$ & $\begin{array}{c}\text { Cement } \\
\left(\mathrm{kg} / \mathrm{m}^{3}\right)\end{array}$ & $\begin{array}{c}\text { Water } \\
\left(\mathrm{kg} / \mathrm{m}^{3}\right)\end{array}$ & $\begin{array}{c}\text { Fine } \\
\text { Aggregate } \\
\left(\mathrm{kg} / \mathrm{m}^{3}\right)\end{array}$ & $\begin{array}{c}\text { Coarse } \\
\text { Aggregate } \\
\left(\mathrm{kg} / \mathrm{m}^{3}\right)\end{array}$ & $\begin{array}{c}\text { Admix. } \\
\left(\mathrm{kg} / \mathrm{m}^{3}\right)\end{array}$ \\
\hline $\mathrm{F}_{\mathrm{c} 30}$ & 60.0 & 314 & 188 & 729 & 1025 & 1.20 \\
\hline \multicolumn{7}{c}{ Table 3 Mechanical properties of materials } \\
\hline Designation & $\begin{array}{c}\text { slump } \\
(\mathrm{cm})\end{array}$ & $\begin{array}{c}\text { Air content } \\
(\%)\end{array}$ & $\begin{array}{c}\text { Compression } \\
\text { strength } \\
\left(\mathrm{N} / \mathrm{mm}^{2}\right)\end{array}$ & $\begin{array}{c}\text { Young's } \\
\text { modulus } \\
\left(\mathrm{N} / \mathrm{mm}^{2}\right)\end{array}$ \\
\hline C66 & 12.0 & 3.5 & 28.6 & 24600 \\
\hline
\end{tabular}

\section{2 促進腐食試験方法}

Fig. 2 に促進腐食試験の概念図を示す。試験体は28 日間の気中養 生後, Fig.1 に示すエポキシ樹脂コーティングによる防水処置を施し た。エポキシ樹脂硬化後， $3 \% \mathrm{NaCl}$ 水溶液に 24 時間浸漬し, 鉄筋を 陽極，水槽の底面に置いた銅板を陰極として，10 Vの一定直流電圧 による促進腐食試験を開始した。

測定項目は積算電流密度および表面ひび割れ幅である。積算電流 密度に関しては, 各鉄筋のリード線に $2 \Omega$ の抵抗を接続し, この抵 抗間の電圧を 1 時間ごとにデータロガーで計測した。この電圧から 各鉄筋に導入される電流を算定し，促進試験期間中 (約 2.5 か月間) における積算電流密度を随時求めた。

コンクリート表面の腐食ひび割れ幅の測定は，ひび割れの発生以 降, 分解能 $1 / 100 \mathrm{~mm}$ のデジタルマイクロスコープを用いて適宜行っ た。ひび割れ計測位置は，ひび割れ幅が試験体長さ方向に一様とは ならないため, 試験体長さ $300 \mathrm{~mm}$ を 3 等分し, 各区間の最大ひび割 れ幅を計測した。

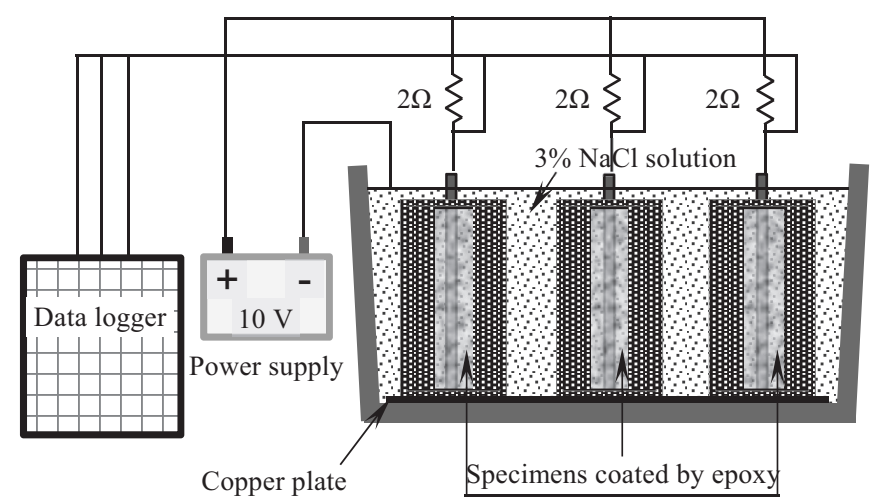

Fig. 2 Overview of accelerated corrosion test

\section{3 割裂引張試験方法}

Table 1 に示す目標積算電流密度に到達した試験体は, JIS 試験方 法 ${ }^{5)}$ に準拠した割裂引張試験を行い，腐食鉄筋を取り出した。割裂 引張試験には，2000kN 万能試験機を使用した。本研究目的は, 高経 年化 RC 建造物の腐食ひび割れに起因するかぶりコンクリート（コ 
ンクリート片）の剥落の危険性を評価し，剥落防止対策に資するこ とである。それ故, 剥落の主要因と考えられる腐食ひび割れ面の割 裂引張強度を定量化し, 剥落の危険性評価の尺度と寸るため, 腐食 ひび割れ面が割裂面となるように, Fig.3 に示すように試験体を加圧 板の間にセットし, 割裂引張試験を行った。

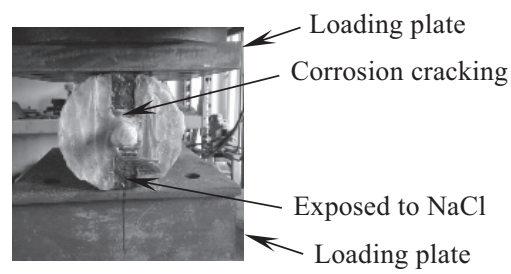

Fig. 3 Overview of splitting tensile test

\section{4 腐食鉄筋の質量測定方法}

割裂引張試験によって取り出した腐食鉄筋は，10\%クエン酸アン モニウム水溶液中に 24 時間浸漬させた。その後, ワイヤーブラシで 腐食生成物を完全に除去した鉄筋腐食後の質量を計測し, 健全時の 質量と比較することによって各鉄筋の質量減少量を実測した。

\section{3 促進腐食実験結果および考察}

\section{1 腐食鉄筋の質量減少量}

Table 4 に各腐食鉄筋の実測による腐食量として, 単位面積当たり の質量減少量 $W_{\text {loss }}\left(\mathrm{mg} / \mathrm{cm}^{2}\right)$ および健全鉄筋からの質量減少率 $(\%)$ を カッコ内に示す。さらに Table 4 には, 積算電流密度からファラデー 則を用いて算出した質量減少量 $\mathrm{W}_{\text {cal }}\left(\mathrm{mg} / \mathrm{cm}^{2}\right)$, 質量減少率 $(\%)$ およ

Table 4 Comparison of measured and estimated corrosion rates

\begin{tabular}{|c|c|c|c|c|}
\hline Designation & No. & $\begin{array}{c}\mathrm{W}_{\text {loss }} \\
\mathrm{mg} / \mathrm{cm}^{2}(\%)\end{array}$ & $\begin{array}{c}\mathrm{W}_{\mathrm{cal}} \\
\mathrm{mg} / \mathrm{cm}^{2}(\%)\end{array}$ & $\mathrm{W}_{\text {loss }} / \mathrm{W}_{\text {cal }}$ \\
\hline \multirow{4}{*}{$\mathrm{C} 66-30^{1)}$} & 1 & $21.4(0.71)$ & $31.3(1.04)$ & 0.68 \\
\hline & 2 & $20.0(0.66)$ & $31.4(1.04)$ & 0.64 \\
\hline & 3 & $18.1(0.60)$ & $31.3(1.04)$ & 0.58 \\
\hline & Ave. & $19.8(0.66)$ & $31.2(1.04)$ & 0.63 \\
\hline \multirow{4}{*}{ C66-100 ${ }^{2)}$} & 1 & 35.2 (1.17) & $104(3.47)$ & 0.34 \\
\hline & 2 & $75.5(2.50)$ & 104 (3.45) & 0.73 \\
\hline & 3 & $41.0(1.36)$ & $104(3.47)$ & 0.39 \\
\hline & Ave. & $50.6(1.67)$ & $104(3.46)$ & 0.49 \\
\hline \multirow{4}{*}{ C66-200 } & 1 & $117(3.89)$ & $210(6.98)$ & 0.56 \\
\hline & 2 & $119(3.96)$ & $208(6.91)$ & 0.57 \\
\hline & 3 & $122(4.05)$ & 209 (6.94) & 0.58 \\
\hline & Ave. & $119(3.97)$ & 209 (6.94) & 0.57 \\
\hline \multirow{4}{*}{ C66-400 } & 1 & $311(10.3)$ & 417 (13.8) & 0.75 \\
\hline & 2 & $311(10.3)$ & $416(13.8)$ & 0.75 \\
\hline & 3 & $299(9.95)$ & 417 (13.9) & 0.72 \\
\hline & Ave. & 307 (10.2) & 417 (13.8) & 0.74 \\
\hline
\end{tabular}

Note 1) Specimens of C66-30 indicate doubtful data because they were left for a while after accelerated corrosion tests.

Note 2) Specimens in bold letter are expected to crack.
び $W_{\text {loss }} / W_{\text {cal }}$ の比率を示している。

腐食生成物が出現するひび割れ発生前の試験体 C66-30 の実測值 $W_{\text {loss }}$ は理論值 $W_{\text {cal }}$ の $60 \%$ 以上となっている。これは, 目標積算電流 密度に到達後も試験体を塩水槽に浸していたため, 通電期間外に腐 食が進行したことに起因しており，参考值である。前報 ${ }^{4)}$ と同様に， 腐食ひび割れの発生後, かぶりコンクリートの抵抗が小さくなるこ とによって，鉄筋を流れる電流量が多くなり，実測值は理論值に近 づいている。前報のかぶり厚さがほぼ等しいR60 矩形断面試験体と 比較すると, 腐食速度は若干速くなっている。これは, 両方向から 塩化物イオンが侵入していることと断面が小さいため, 電気抵抗が 減少したことに起因していると考えられる。

\section{2 積算電流密度と腐食量の関係}

前報 ${ }^{4)}$ で示したように, 腐食速度はひび割れ発生前後で異なって いることが予想される。積算電流密度と鉄筋腐食量の関係を Fig.4 に 示す。৩マーカーはひび割れ前，ロマーカーはひび割れ発生時，○マ 一カーはひび割れ発生後の実測腐食量を示している。破線は，鉄筋 腐食量は積算電流密度に比例するとして線形補間した場合の鉄筋腐 食量の評価であるが，鉄筋腐食量を過大評価している。したがって 積算電流密度から内部鉄筋腐食量を評価する場合，ひび割れ発生前 後で腐食速度が異なることを考慮し，前報と同様にひび割れ発生時 を折れ点とするバイリニアを用いて補間する。

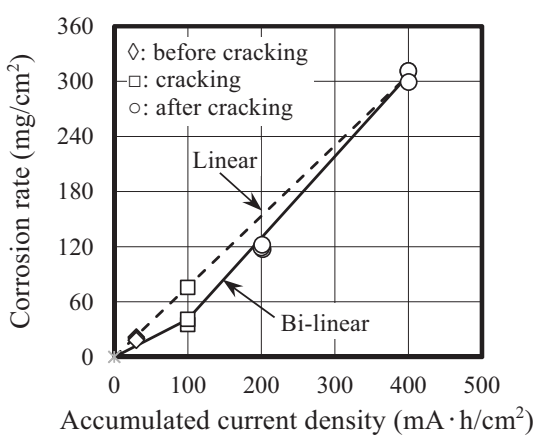

Fig. 4 Corrosion rate behavior with increasing current density

\section{3 腐食ひび割れの進展挙動}

腐食量の最も大きいC66-400 シリーズの最終ひび割れ性状の写真 を Fig. 5 に示す。両方向を塩水に暴露し, 腐食ひび割れの誘導を試み たが，一方の暴露面にひび割れが発生すると，そのひび割れがほぼ 直線状に進展・拡幅し，他方の暴露面にひび割れが発生することは なかった。

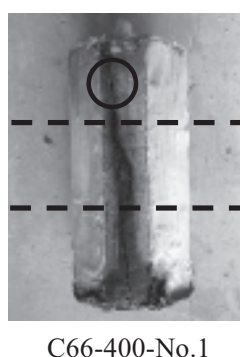

$\bigcirc$

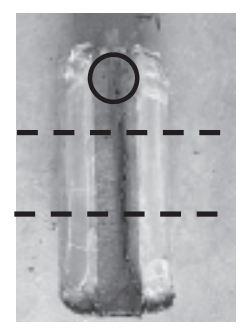

C66-400-No.2

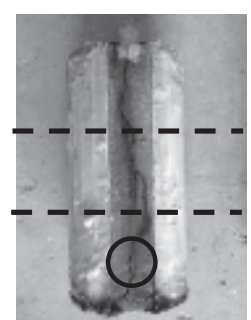

C66-400-No.3
Location of maximum crack width

Fig. 5 Final corrosion crack patterns for C66-400 series 
腐食ひび割れ発生後も促進腐食を継続した試験体 C66-200 シリー と C66-400 シリーズに関しては, マイクロスコープを用いて随時ひ び割れ幅を計測した。ひび割れ幅と鉄筋腐食量の関係を Fig. 6 と Fig.7 に示す。左図は測定点 3 箇所の最大ひび割れ幅, 右図は測定点 3 箇所の平均ひび割れ幅, 各マーカーは測定点である。ひび割れ幅 計測時の鉄筋腐食量については, バイリニア補間によって評価した。 前報 ${ }^{4)}$ の矩形断面のひび割れ挙動と比較するために, R60-400 シリ ーズの試験結果を Fig.8 に再掲する。ひび割れ発生時の腐食量は $50 \mathrm{mg} / \mathrm{cm}^{2}$ 程度とほぼ同じであるが, 円形断面 C66-400 シリーズのひ び割れの拡幅は矩形断面より大きい。これは, 円形断面は矩形断面 より断面積が小さく, 腐食生成物を蓄積できる細孔部が少なくなる ため, 腐食生成物がひび割れ面により集中寸ることに起因している と思われる。この理由により, 前報の腐食ひび割れ幅から鉄筋腐食 量を評価する実験式を提案する際, 円形断面のデータを除外した。 全試験体を通して, ひび割れ幅が 0.2 から $0.4 \mathrm{~mm}$ 程度になると, 腐 食生成物が連結したひび割れを通して試験体外に流出するため, 拡 幅速度が低下しているのがわかる。

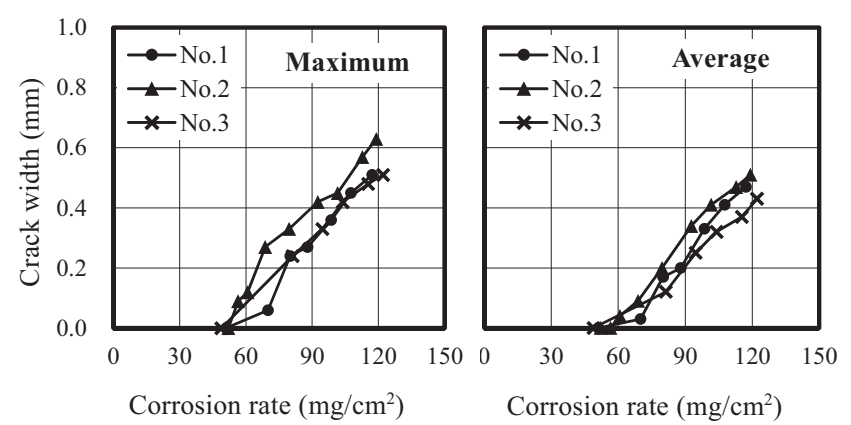

Fig. 6 Crack behaviors caused by corrosion for C66-200 series

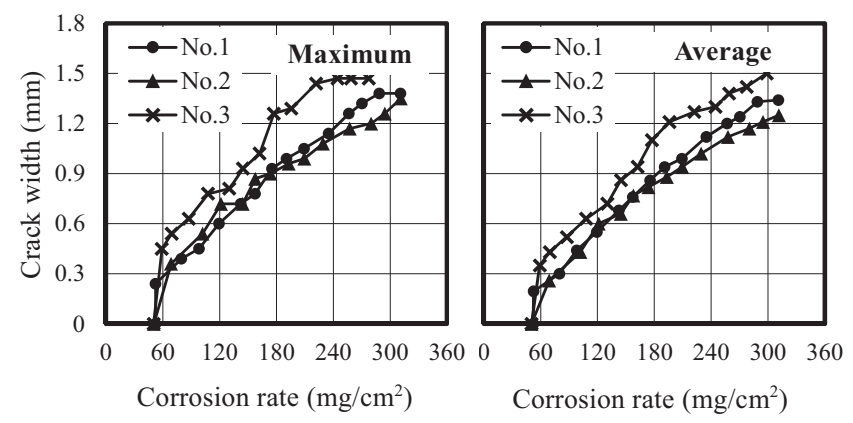

Fig. 7 Crack behaviors caused by corrosion for C66-400 series

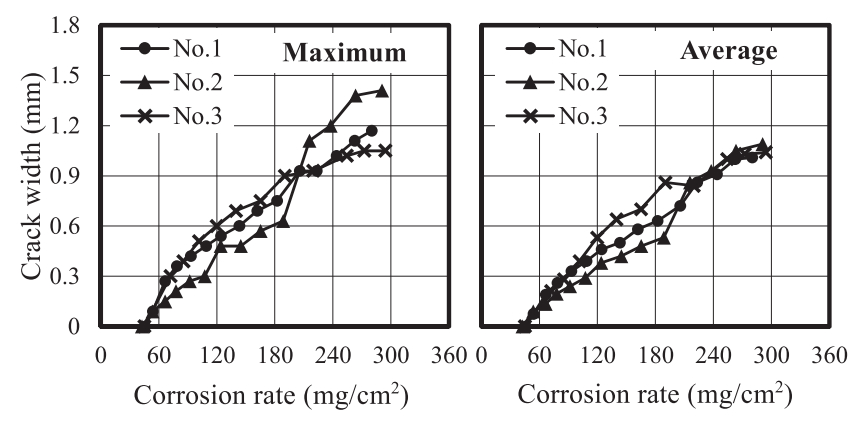

Fig. 8 Crack behaviors caused by corrosion for R60-400 series

\section{4 割裂引張試験結果および考察}

4.1 腐食鉄筋を有するコンクリートの割裂引張強度

Table-5 に腐食鉄筋を有するコンクリートの割裂引張強度を示す。 割裂引張強度の算出は, 通常の割裂引張試験 ${ }^{5}$ に対する強度式 (1) 式 を代用するが，鉄筋部（最大径 $18 \mathrm{~mm}$ ）は考慮しない。

$$
\sigma_{\mathrm{t}}=\frac{2 \mathrm{P}}{\pi \mathrm{dl}}
$$

ここに，展は割裂引張強度 $\left(\mathrm{N} / \mathrm{mm}^{2}\right), \mathrm{P}$ は最大荷重 $(\mathrm{kN}), \mathrm{d}$ は鉄 筋最外径を除いた $132 \mathrm{~mm}$ ， I は試験体長さ $300 \mathrm{~mm}$ である。Fig. 9 に

\begin{tabular}{|c|c|c|c|c|}
\hline Designation & No. & $\begin{array}{c}\mathrm{W}_{\text {loss }} \\
\mathrm{mg} / \mathrm{cm}^{2}(\%)\end{array}$ & $\begin{array}{c}\text { Split strength } \\
\sigma_{\mathrm{t}}\left(\mathrm{N} / \mathrm{mm}^{2}\right)\end{array}$ & $\begin{array}{l}\text { Corrected strength } \\
\sigma_{\mathrm{t}} \text { (corr.) }\left(\mathrm{N} / \mathrm{mm}^{2}\right)\end{array}$ \\
\hline \multirow{4}{*}{ C66-0 } & 1 & 0 & 1.43 & - \\
\hline & 2 & 0 & 2.25 & - \\
\hline & 3 & 0 & 1.64 & - \\
\hline & Ave. & 0 & 1.77 & - \\
\hline \multirow{4}{*}{ C66-30 } & 1 & $21.4(0.71)$ & 1.94 & - \\
\hline & 2 & $20.0(0.66)$ & 1.55 & 一 \\
\hline & 3 & $18.1(0.60)$ & 2.07 & - \\
\hline & Ave. & $19.8(0.66)$ & 1.85 & - \\
\hline \multirow{4}{*}{ C66-100 } & 1 & $35.2(1.17)$ & 1.73 & 一 \\
\hline & 2 & $75.5(2.50)$ & 1.96 & - \\
\hline & 3 & $41.0(1.36)$ & 1.85 & - \\
\hline & Ave. & $50.6(1.67)$ & 1.85 & - \\
\hline \multirow{4}{*}{ C66-200 } & 1 & $117(3.89)$ & 1.31 & 0.79 \\
\hline & 2 & $119(3.96)$ & 1.29 & 0.77 \\
\hline & 3 & $122(4.05)$ & 1.46 & 1.09 \\
\hline & Ave. & 119 (3.97) & 1.35 & 0.88 \\
\hline \multirow{4}{*}{ C66-400 } & 1 & $311(10.3)$ & 1.04 & 0.25 \\
\hline & 2 & $311(10.3)$ & 1.19 & 0.55 \\
\hline & 3 & $299(9.95)$ & 1.21 & 0.59 \\
\hline & Ave. & $307(10.2)$ & 1.14 & 0.46 \\
\hline
\end{tabular}

Note; $\sigma_{\mathrm{t}}$ (corr.) is roughly estimated by a corrosion cracking surface.

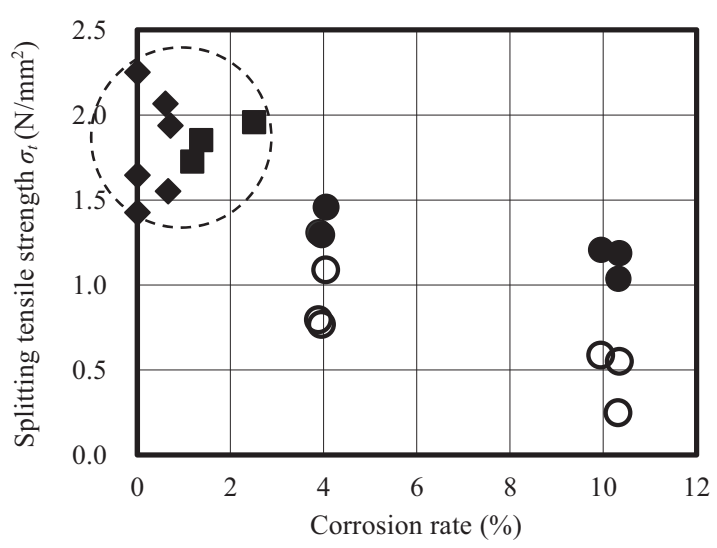

Fig. 9 Relationship between splitting strength and corrosion rate 
(1) 式による鉄筋腐食量と割裂引張強度の関係をプロットしている。 これらの図表からわかるように, 腐食生成物がコンクリート表面に 現れる積算通電量 $100 \mathrm{~mA} \cdot \mathrm{h} / \mathrm{cm}^{2}$ (腐食量 $1.67 \%$ ) までは, 腐食ひび割 れが連続しているわけではなく, 鉄筋腐食による割裂引張強度の低 下はほとんど見られない。しかしながら腐食ひび割れが連結し, 腐 食生成物の流出が多くなる積算通電量 $200 \mathrm{~mA} \cdot \mathrm{h} / \mathrm{cm}^{2}$ (腐食量 $3.97 \%$ ) で約 $26 \%$, 促進腐食試験終了の積算通電量 $400 \mathrm{~mA} \cdot \mathrm{h} / \mathrm{cm}^{2}$ （腐食量 10.2\%）で約 37\% 低下している。

割裂引張試験後の代表的なひび割れ性状を Fig. 10 に示す。腐食ひ び割れが表面に出現しなかった試験体を含め, 割裂荷重線はすべて 相対する暴露面の中央としたが，割裂ひび割れは腐食生成物の残留 する腐食ひび割れと一致しており，その他の腐食ひび割れおよび割 裂ひび割れは見られなかった。それ故, 本研究では Fig.9 の割裂強度 を腐食ひび割れ面における割裂引張強度として扱う。円形断面 C66 シリーズについては, Fig. 1 に示すように, 2 方向から塩水を侵入す る計画設計であったが, 3.3 節で述べたように, 実際には 1 方向の みから腐食生成物が流出したため, その方向を文ーカーで示寸。 この図からわかるように, 腐食生成物は, 流出経路が定まるとその 経路に集中し, 反対側に侵入する腐食生成物の量は少なくなってい る。したがって, 前述の割裂引張強度は腐食ひび割れが表面に達し た側（腐食側）と反対側の腐食生成物がほとんど侵入しなかった側 （健全側）の割裂引張面の平均強度となるため, 腐食ひび割れ面に 対する割裂引張強度を過大評価していると考えられる。そこで，1） 式による割裂引張強度がほとんど変わらなかった腐食ひび割れ発生 前の試験体（Fig.9 の円形破線）の平均值を健全なコンクリートの割 裂引張強度とし, 健全なコンクリート（健全側）が負担する荷重分 を差し引いて，腐食側に対する割裂引張強度 $\sigma_{\mathrm{t}}$ (corr.)を推定した。 Table 5 に $\sigma_{\mathrm{t}}$ (corr.) として, また Fig. 9 に白抜きマーカーで示す。健 全側に対して腐食側の割裂引張強度は, 腐食量 $3.97 \%$ で約 $1 / 2$, 腐食 量 $10.2 \%$ で約 $1 / 4$ に低下寸るが, 実際には健全なコンクリートとみ なした健全側にも, ある程度腐食生成物が侵入しているため, 過小 評価と考えられる。より詳細な腐食ひび割れ性状に応じた割裂強度 に関しては 5 節の有限要素解析で検討する。

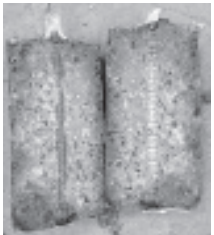

C66-30-No.3

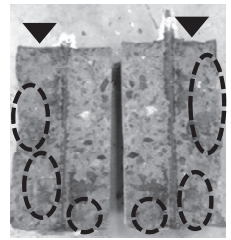

C66-100-No.2

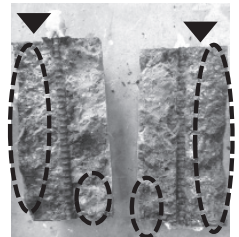

C66-400-No.3
Cracking side

Corrosion product

Fig.10 Traces of corrosion product after splitting off

\section{2 鉄筋腐食量による割裂引張強度低下率の定式化}

高経年化 RC 建造物の鉄筋腐食ひび割れに起因するかぶりコンク リート (コンクリート片) の剥落に関しては, 鉄筋腐食量からかぶ りコンクリートの剥落危険度を評価できるように, 鉄筋腐食量によ る割裂引張強度低下を推定できる回帰式を提案する。鉄筋腐食に伴 う割裂引張強度保有は, 健全試験体の割裂引張強度を 1 とする比率 で表現する。定式化は健全試験体で 1 , 腐食量無限大で 0 となる関

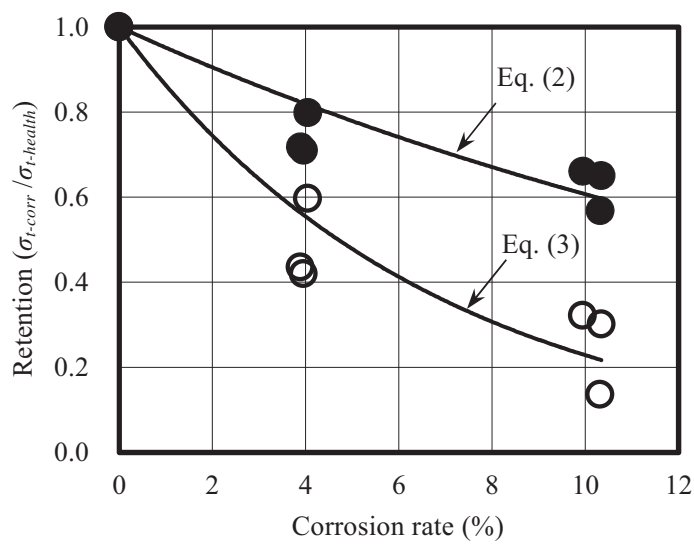

Fig.11 Retention of splitting tensile strength with corrosion rate

数として, 簡便な指数関数 $\exp (-\mathrm{ax})$ を使用する。 Fig.9 の平均割裂引 張強度（黒塗り）および腐食部割裂引張強度（白抜き）に対する回 帰式は，それぞれ(2)および(3)式となり，Fig.11に示す。ただし，腐 食ひび割れがコンクリート表面に現れる(腐食量 $1.5 \%$ ～ $2.0 \%$ 程度) までは割裂引張強度の低下は考慮する必要はない。

$$
\begin{aligned}
& \gamma=\sigma_{\mathrm{t}(\text { corr })} / \sigma_{\mathrm{t} \text { (health) }}=\exp (-0.05 \mathrm{x}) \\
& \gamma=\sigma_{\mathrm{t}(\text { corr })} / \sigma_{\mathrm{t} \text { (health) }}=\exp (-0.15 \mathrm{x})
\end{aligned}
$$

ここで， $\sigma_{\mathrm{t} \text { (corr) }}$ は鉄筋腐食ひび割れにより低下した平均(2)式または 腐食部(3)式の割裂強度 $\left(\mathrm{N} / \mathrm{mm}^{2}\right) ， \sigma_{\mathrm{t}(\text { healyh) }}$ は健全鉄筋時の割裂強度 $\left(\mathrm{N} / \mathrm{mm}^{2}\right)$ および $\mathrm{x}$ は腐食量 $(\%)$ であり，相関係数は (2)式で 0.84，(3) 式で 0.86 である。腐食量 $10 \%$ まで， 2 次式の回帰式で近似すると高 い相関が得られるが，データ点数が少ないことや腐食量 $10 \%$ 以上の 推定ができないことから，簡便な式を提案した。

Fig.1 に示寸ような促進腐食後の柱試験体は, クレーンによる移動 やタガネによる僅かな衝撃によってかぶりコンクリートが腐食ひび 割れ面から剥落しており，腐食ひび割れ面の割裂強度（引張強度） 低下がその要因であると推察できる。それ故, 腐食ひび割れ面の割 裂引張強度によって, かぶりコンクリートの剥落を直接評価するこ とはできないが, Fig. 11 に示した腐食ひび割れ面の割裂引張強度低 下割合は, 剥落危険性を評価する際の尺度として使用することは可 能と思われる。

\section{5 有限要素解析による腐食ひび割れ面の割裂引張強度の検討}

\section{1 解析モデル}

4 節で述べたように, 補正後の腐食ひび割れ面に対する割裂引張 強度は，腐食ひび割れが表面に現れなかった側はすべて健全部と仮 定したため下限值と考えられる。実際の腐食ひび割れ部位の割裂引 張強度は, 補正前と補正後の間に存在すると考えるのが妥当である。 そこで腐食ひび割れ面の割裂引張強度をより詳細に検討するため, 有限要素解析を行う。ただし, 実験結果は割裂時の最大荷重のみで あるため, Table 5 の割裂引張強度を使用して, 主に腐食ひび割れ面 の破壊エネルギーについて考察する。解析対象試験体は健全試験体 として C66-0，30，100 の割裂引張強度平均值 $1.82 \mathrm{kN} / \mathrm{mm}^{2}$ と鉄筋腐 食試験体として $666-400$ (同 $1.14 \mathrm{kN} / \mathrm{mm}^{2}$ ) の 2 種類である。

解析モデルを Fig.12 に示す。割裂引張試験体は対称性のため半分 
のみを解析対象とし, 平面応力要素を使用する。対称面はローラー 支持とし，コンクリートの割裂引張試験の性質上, 最も非線形性が 集中する割裂面には，Fig.13 に示すバイリニア型引張軟化特性 ${ }^{6} を$ 有するインターフェース要素を設ける。鉄筋部のインターフェース 要素は, コンクリートとの界面を想定して小さな引張強度 $0.1 \mathrm{~N} / \mathrm{mm}^{2}$, さらにひび割れ後の急激な荷重低下を避けるために，鉄筋とコンク リートのかみ合いを考慮してせん断保有 $1 \mathrm{~N} / \mathrm{mm}^{2}$ を仮定した。これ らの数值は鉄筋部が 1 割強と小さいため, 解析結果に及ぼす影響も 小さい。インターフェース以外のコンクリートに関しては, 圧縮領 域は Drucker-Prager (上昇域は土木学会の 2 次式 ${ }^{7)}$, 内部摩擦角は $10^{\circ}$ $\left.{ }^{8)}\right)$ とし，引張領域は Rankine による Tension-cutoff ${ }^{9)}$ を適用する。ま た，鉄筋と而圧板は弾性係数 $205000 \mathrm{~N} / \mathrm{mm}^{2}$ の線形要素とした。

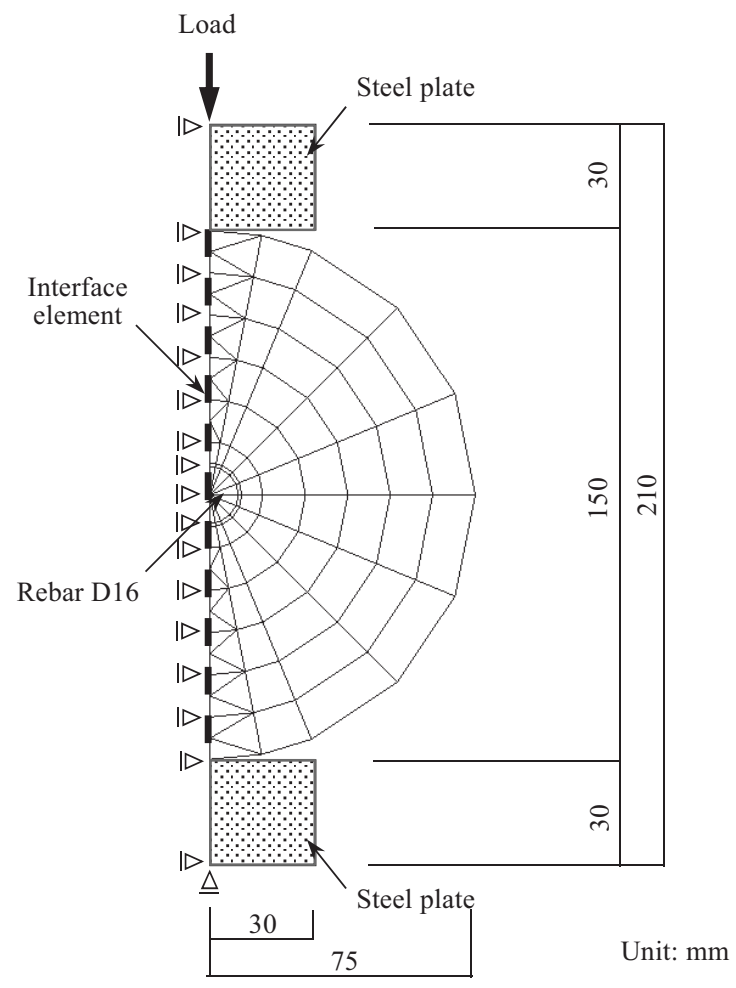

Fig. 12 FE mesh and boundary condition for splitting tensile test

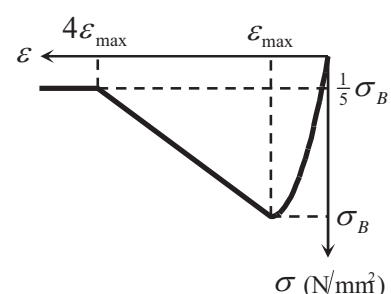

Compressive stress strain curve

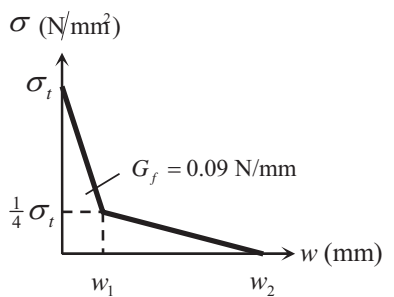

Tensile stress crack-width curve

\begin{tabular}{|c|c|c|c|c|c|c|}
\hline $\begin{array}{c}\sigma_{\mathrm{B}} \\
\mathrm{N} / \mathrm{mm}^{2}\end{array}$ & $\varepsilon_{\max }$ & $\begin{array}{c}\mathrm{E}_{\mathrm{c}} \\
\mathrm{N} / \mathrm{mm}^{2}\end{array}$ & $\begin{array}{c}\sigma_{\mathrm{t}} \\
\mathrm{N} / \mathrm{mm}^{2}\end{array}$ & $\begin{array}{c}\mathrm{W}_{1} \\
\mathrm{~mm}\end{array}$ & $\begin{array}{c}\mathrm{W}_{2} \\
\mathrm{~mm}\end{array}$ & $v$ \\
\hline 28.6 & -0.002 & 24600 & 1.82 & 0.044 & 0.2 & 0.2 \\
\hline
\end{tabular}

$\mathrm{G}_{\mathrm{f}}$ : Fracture energy, $v$ : Poisson's ratio

Fig. 13 Mechanical properties and analytical model for concrete

\section{2 解析結果および考察}

はじめに健全試験体の解析結果を Fig.14 に示す。載荷はいずれも $0.01 \mathrm{~mm}$ 増分の変位制御である。Table 5 に示した健全試験体の割裂 引張強度と文献 6)の引張軟化特性を用いることによって, 割裂引張 試験の最大荷重 $113.5 \mathrm{kN}$ を再現できている。また，同図には割裂面 (インターフェース要素) 以外のコンクリート要素を線形と仮定し た解析結果を破線で示している。両者の挙動はほぼ同じであり, 割 裂面の非線形挙動, すなわち引張軟化特性が支配的であることがわ かる。このことは，Fig. 15 に示す最大荷重時の最小主応力分布とひ び割れひずみ分布からも推察できる。最小主応力の絶対值は載荷点 直下の領域を除いて $10 \mathrm{~N} / \mathrm{mm}^{2}$ 以下であり，ひび割れひずみも極めて 小さい。

Fig. 16 に鉄筋腐食試験体 C66-400 の解析結果を示す。解析結果に 大きく影響する引張軟化特性は次のように仮定した。(1) C66-400の 割裂引張強度 $\left(1.14 \mathrm{~N} / \mathrm{mm}^{2}\right.$ 健全試験体の $63 \%$ ) を使用するが，ひび割 れ幅 (Fig.13の $\left.\mathrm{W}_{1}, \mathrm{~W}_{2}\right)$ は健全試験体と同じ $\left(0.63 \sigma_{\mathrm{t}}+1.0 \mathrm{~W}\right)$ とすると, 解析結果は実験值 $71.1 \mathrm{kN}$ より約 $15 \%$ 大きく, 破壊エネルギーを過 大評価している。(2) 割裂引張強度の外に, 対応するひび割れ幅 (Fig.13の $\left.\mathrm{W}_{1}, \mathrm{~W}_{2}\right)$ も同じ比率で低下 $\left(0.63 \sigma_{\mathrm{t}}+0.63 \mathrm{~W}\right)$ させると, 割裂引

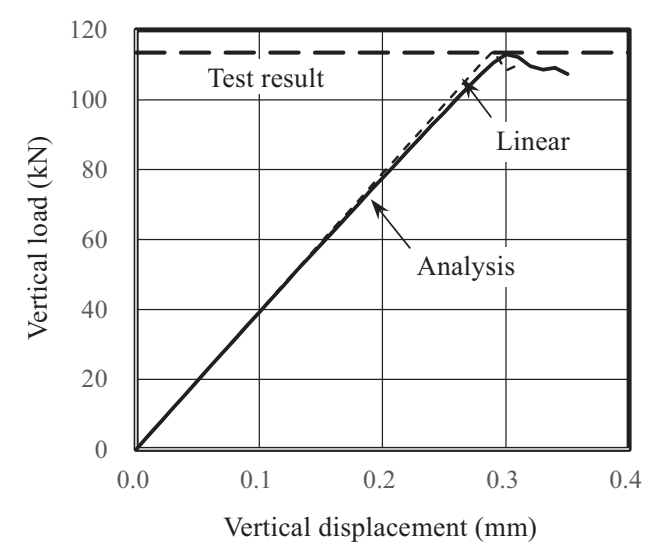

Fig. 14 Comparisons of test and analysis for health specimen

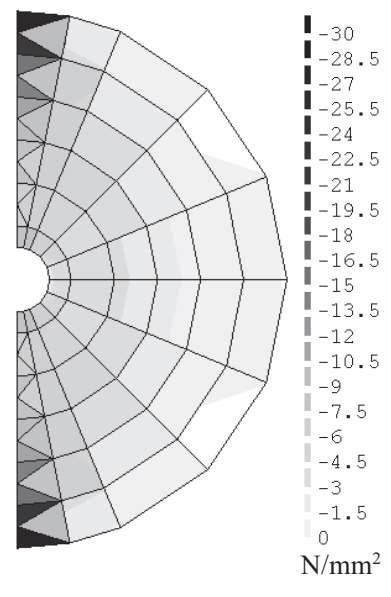

$\sigma_{2 \min .}=-27.8 \mathrm{~N} / \mathrm{mm}^{2}$

(1) Minor principal stress

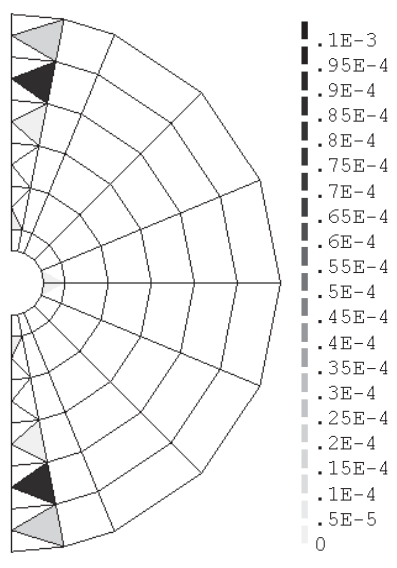

$\varepsilon_{\text {cr max. }}=85 \mu$

(2) Crack strain
Fig. 15 Minor principal stress and crack strain distribution at peak 


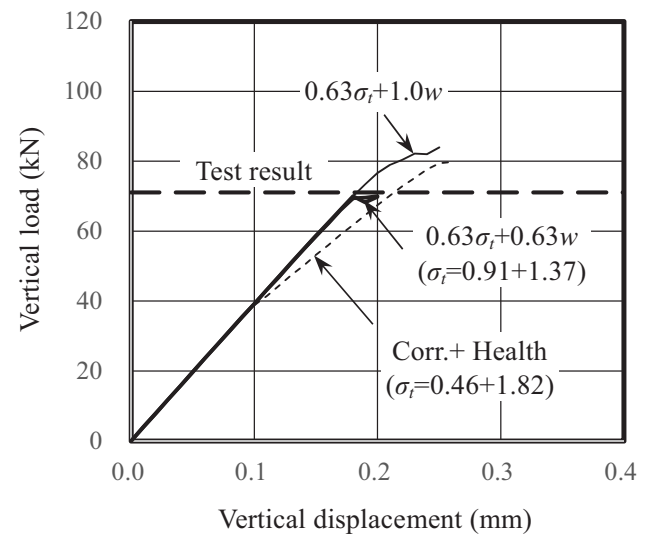

Fig. 16 Comparisons of test and analysis for corroded specimen

張試験の最大荷重 $71.1 \mathrm{kN}$ とほぼ同じ結果が得られた。したがって, 腐食ひび割れ面の破壊エネルギーについては，強度低下だけでなく ひび割れ幅も考慮する必要があり, 強度低下率の 2 乗で低下寸ると 思われる。そこで, (2)の方針に従って，4 節で仮定した腐食ひび割 れがコンクリート表面に現れた側の割裂引張強度を $0.46 \mathrm{~N} / \mathrm{mm}^{2}$, 反 対側は健全とみなして $1.82 \mathrm{~N} / \mathrm{mm}^{2}$ とした解析結果 $\left(\sigma_{\mathrm{t}}=0.46+1.82\right)$ を 破線で示す。剛性は低下寸るが，最大荷重は実験值を上回り，整合 性が悪い。最大荷重が実験值とほぼ同じとなる割裂引張強度の組み 合わせは，腐食ひび割れ側で $0.91 \mathrm{~N} / \mathrm{mm}^{2}$ ，健全側で $1.37 \mathrm{~N} / \mathrm{mm}^{2}$ とな り，ひび割れが表面に達した腐食側の割裂引張強度は，ひび割れ幅 $1 \mathrm{~mm}$ 強(Fig.7 参照) で, 健全時より約 50\%低下寸る結果となった。 さらに解析精度を向上するためには, 破壊勒性試験による腐食ひ び割れ面に対する破壊エネルギーなどのデータの蓄積が必要である。

\section{6. まとめ}

直径 $150 \mathrm{~mm}$, 長さ $300 \mathrm{~mm}$ のコンクリートシリンダーの回転軸に 鉄筋 (D16) を有する試験体の促進腐食試験を行い，腐食鉄筋を取り 出寸際, 腐食ひび割れ面に対して割裂引張試験を行った。促進腐食 試験中のひび割れ進展挙動および鉄筋腐食量と腐食ひび割れ面の割 裂引張強度の関係を明らかにし，かぶりコンクリート剥落の危険性 評価や剥落防止対策を行う際の指標として, 腐食量の増大に伴うコ ンクリートの割裂引張強度低下率を推定する簡便な式を提案した。 主な結論を以下に示す。

1) 積算電流密度から鉄筋の腐食量を推定する場合, 腐食速度はひ び割れ発生前後で異なるため, ひび割れ発生時を折れ点とする バイリニアを用いて補間した。

2） 円形断面は矩形断面より断面積が小さく, 腐食生成物を蓄積で きる細孔部が少なくなるため, 同じ腐食量に対する腐食ひび割 れの拡幅は，矩形断面より大きくなった。

3）鉄筋腐食による割裂引張強度は, 腐食生成物がコンクリート表 面に現れる腐食量 $1.7 \%$ までは, 腐食ひび割れが連続しているわ けではなく，ほとんど変化はなかった。

4）鉄筋腐食による平均割裂引張強度は，連結した腐食ひび割れを 通して，腐食生成物の流出が多くなる腐食量 $3.97 \%$ で約 $26 \%$, 促進腐食試験終了の腐食量 $10.2 \%$ で約 37\% 低下した。
5）コンクリートの剥落の危険性評価や防止計画に資するため，鉄 筋腐食量の増大に伴うコンクリートの割裂引張強度低下率を 推定する簡便な式を提案した。

6) 腐食ひび割れは割裂面に対して, 一様に進展するのではなく, 偏在が見られたため, 有限要素解析を用いて偏在の影響を検討 した。

7) 割裂引張試験の力学挙動は, 割裂面の引張軟化特性が支配的で あり，腐食ひび割れ面に対しては，割裂引張強度だけでなくひ び割れ幅も同じ割合で低減する必要があった。

前報 ${ }^{4)}$ のコンクリート表面の腐食ひび割れ幅から内部鉄筋の腐食 量を推定する式と今回の鉄筋腐食量によるコンクリートの割裂引張 強度低下率を併せて用いると, 計測が容易なコンクリート表面の腐 食ひび割れ幅から，内部鉄筋の腐食量および割裂引張強度低下率を 尺度とするかぶりコンクリート剥落危険性の推定が可能となる。さ らに剥落危険性の評価精度を向上させるためには，鉄筋腐食に起因 するかぶりコンクリートの剥落に対して，鉄筋腐食量を実測するな ど, データを蓄積していく必要がある。

\section{謝辞}

本研究で使用した鉄筋は東京鉄鋼（株）からご提供頂きました。 また，本研究の一部は原子力規制庁の高経年化技術評価高度化事業 ならびに東京工業大学フロンティア材料研究所の全国共同利用によ りました。ここに厚く御礼申し上げます。

\section{参考文献}

1) 篠原保二, 覚張雄一郎, 丸山裕生, 南正樹, 宮内博之: 塩害環境下にお ける $\mathrm{RC}$ 柱の鉄筋腐食ひび割れ挙動および横補強筋のひずみ上昇, 日本 建築学会構造系論文集, Vol.81, No.720, pp. 323-333, 2016.2

2) C. Andrade, C. Alonso, and F. J. Molina : Cover cracking as a function of bar corrosion: Part I- Experimental test, Materials and Structures, 26, pp. 453464, 1993.10

3) 橘高義典, LE PHONG NGUYEN, 塚越雅幸, 松沢幸一: 鉄筋コンクリー ト表面のひび割れ発生時の鉄笳腐食量に関する検討，コンクリート工 学年次論文報告集, Vol.33, No1, pp. 1145-1150, 2011.7

4) 篠原 保二, 丸山 裕生, 山下 海斗, 南 正樹 : 鉄笳の腐食量と腐食ひび 割れ幅の関係, 日本建築学会大会学術講演梗概集, 材料施工, pp. 121 $126, \quad 2016.8$

5) 新日本法規 : 建築関係 JIS 要覧 (1-A), A1113 コンクリートの割裂引張 強度試験方法, 2006 年 改正

6) 篠原保二, 安部武雄, 古村福次郎：ノッチ深さ, 載荷速度, 骨材寸法, 水セメント比, 載荷法, 養生および材令がコンクリートの曲げ試験体の 引張軟化特性に及ぼす影響, 日本建築学会構造系論文報告集, No.442, pp.13〜22, 1992.12

7) 土木学会：コンクリート標準示方書 [設計編], 2012.9

8) Kupfer, H, Hilsdorf, H K and RUSCH, H : Behavior of Concrete Under Biaxial Stress, ACI Journal, pp.656 666, 1969.8

9) Chen, W. F. : Plasticity in Reinforced Concrete, McGraw-Hill Book Company, 1982 


\title{
CRACKING BEHAVIORS CAUSED BY CORRODING BARS AND RISK ASSESSMENT OF CONCRETE PEELING-OFF
}

\author{
Yasuji SHINOHARA*, Hiroki MARUYAMA**, Kaito YAMASHITA*** \\ and Jeongsoo $N A M^{* * * *}$ \\ * Assoc. Prof., Laboratory for FIRST, Tokyo Institute of Technology, Dr.Eng. \\ ** Shimizu Corporation, Master of Engineering \\ *** Grad. Stud., Dept. of Environmental Sci. and Tech., Tokyo Institute of Technology \\ **** Researcher, Laboratory for Materials and Structures, Tokyo Institute of Technology, Dr.Eng.
}

The issue on an aged deterioration to a reinforced concrete (RC) building is revealing in recent years. Especially, a falling cover concrete is an urgent subject since it may cause harm to the surrounding people. Number of experimental studies on an aged deterioration have been performed to relate the corrosion cracking appearance on the concrete surface with the corrosion ratio of steel bars. It seems that corrosion cracking propagation also induces cover concrete to peel off. However, there is almost no study on the risk of exfoliation of a cover concrete.

Accelerated corrosion tests were conducted to estimate the splitting tensile strength before and after corrosion cracking appearance on the concrete surface and to assess the risk of falling cover concrete. The specimens are concrete cylinders having $150 \mathrm{~mm}$ in diameter and $300 \mathrm{~mm}$ in length, and a single reinforcement of D16 was installed right in the center of the cylinder. All surfaces except for exposed opposite faces of 50 mm in width were coated by epoxy resin to avoid penetration of $\mathrm{NaCl}$ solution. The variable factor is accumulative current density $(0,30,100,200$ and 400 $\left.\mathrm{mA} \cdot \mathrm{h} / \mathrm{cm}^{2}\right)$.

The specimens were cured for 28 days before accelerated corrosion test. During the accelerated corrosion test, the specimens were placed in the tank containing $3 \%$ of $\mathrm{NaCl}$ solution. A direct-constant 10 voltage was given and the current was monitored and recorded using a data logger in 60 minutes increments. The cracks on the concrete surface were visually observed and the crack width at certain locations was frequently measured using a digital microscope having a resolution of $0.01 \mathrm{~mm}$. After accelerated corrosion tests, the corroded steel bars were removed from the surrounding concrete by performing a split tensile test to evaluate a splitting tensile strength on the corrosion cracking surface. A removed bar was soaked into $10 \%$ diammonium hydrogen citrate solution. After chemically and mechanically cleaning, the weight loss of corroded rebars was measured

Since a corrosion rate before cracking was slower and increased after cracking, a corrosion ratios was estimated from the accumulative current density and using a bi-linear interpolation having a break point at cracking. The circular cross section was smaller than the rectangular cross section, and the pores to accumulate a corrosion product decreased, as a result, the corrosion crack width of a circular specimen became larger than that of a rectangular specimen. Split tensile test results indicated that the splitting tensile strength before cracking (up to corrosion ratio of $1.7 \%$ ) nearly didn't deteriorate due to an occasional stain of corrosion product on the concrete surface, however, it gradually decreased after outflowing of corrosion product from a connected crack. It was reduced by $26 \%$ and $37 \%$ when the corrosion ratio increased to $4 \%$ and $10 \%$ respectively. A simple model was proposed to assess a retention factor of splitting tensile strength with increasing corrosion.

Furthermore, a finite element analysis was conducted on the split tensile specimen to investigate a fracture energy of a cracked surface by corrosion because the corrosion crack did not progress uniformly but was unevenly distributed to the splitting surface. Analytical results showed that the mechanical behavior of the splitting tension test was overwhelmingly dominated by the tensile softening properties of the splitting surface and not only the splitting tensile strength but the crack width should be reduced similarly to obtain a result to be consistent with an experimental strength. Further study is required to improve a prediction of falling concrete from a width of corrosion cracking on the concrete surface due to the sensitivity to tensile softening properties and corrosion level. 